\title{
Antimicrobial activity of phenolic compounds identified in wild mushrooms, SAR analysis and docking studies
}

\author{
Maria José Alves ${ }^{1,2,3}$, IsAbel C.F.R. Ferreira, ${ }^{3,}$, Hugo J.C Froufe ${ }^{3}$, Rui M.V. \\ Abreu $^{3}$, Anabela Martins $^{3}$, Manuela Pintado $^{1, *}$
}

${ }^{a} C B Q F-E s c o l a$ Superior de Biotecnologia - Universidade Católica Portuguesa Porto, Rua Dr. António Bernardino de Almeida, 4200 - 072 Porto, Portugal.

${ }^{b}$ Centro Hospitalar de Trás-os-Montes e Alto Douro- Unidade de Chaves, Av. Dr. Francisco Sá Carneiro, 5400-249 Chaves, Portugal.

${ }^{c}$ CIMO/ESA, Instituto Politécnico de Bragança, Campus de Santa Apolónia, Apartado 1172, 5301-855 Bragança, Portugal.

*Authors to whom correspondence should be addressed (e-mail: iferreira@ipb.pt, telephone +351-273-303219, fax +351-273-325405; e-mail: mpintado@porto.ucp.pt, telephone $+351-22-5580097$, fax $+351-22-5090351)$.

Running Head: Antimicrobial activity of phenolic compounds 


\section{Abstract}

Aim and Methods: Although the antimicrobial activity of extracts from several mushroom species have been reported, studies with the individual compounds present in that extracts are scarce. Herein, the antimicrobial activity of different phenolic compounds identified and quantified in mushroom species from all over the world was evaluated. Furthermore, a structure activity relationship (SAR) analysis and molecular docking studies were performed, in order to provide insights in the mechanism of action of potential antimicrobial drugs for resistant microorganisms.

Results: 2,4-Dihydroxybenzoic and protocatechuic acids were the phenolic compounds with higher activity against the majority of Gram negative and Gram positive bacteria. Furthermore, phenolic compounds inhibited more MRSA than methicillin sensible Staphylococcus aureus. MRSA was inhibited by 2,4-dihydroxybenzoic, vanillic, syringic $(\mathrm{MICs}=0.5 \mathrm{mg} / \mathrm{mL})$ and $p$-coumaric $(\mathrm{MIC}=1 \mathrm{mg} / \mathrm{mL})$ acids, while these compounds at the same concentrations had no inhibitory effects against methicillin sensible Staphylococcus aureus.

Conclusions: The presence of carboxylic acid $(\mathrm{COOH})$, two hydroxyl $(\mathrm{OH})$ groups in para and ortho positions of the benzene ring, as also a methoxyl $\left(\mathrm{OCH}_{3}\right)$ group in the meta position seems to be important for anti-MRSA activity.

Significance and Impact of the Study: Phenolic compounds could be used as antimicrobial agents, namely against some microorganisms resistant to commercial antibiotics.

Keywords: Wild mushrooms; Antimicrobial activity; Clinical isolates; SAR; Docking 


\section{Introduction}

In recent years, there is an increasing number of reports on phenolic compounds in different mushroom species. Phenolic acids including benzoic and cinnamic acid derivatives have been pointed out as the most common. Among benzoic acid derivatives, $p$-hydroxybenzoic, protocatechuic, gallic, vannilic and syringic acids were identified in different mushroom species (Puttaraju et al. 2006; Kim et al. 2008; Barros et al. 2009; Heleno et al. 2011; Reis et al. 2011; Vaz et al. 2011; Heleno et al. 2012)

(Table 1). The identification of cinnamic acid and its derivatives such as $p$-coumaric, $o$ coumaric, caffeic, ferulic and chlorogenic acids was also described (Mattila et al. 2001; Valentão et al. 2005; Puttaraju et al. 2006; Barros et al. 2008; Kim et al. 2008; Heleno et al. 2011; Reis et al. 2011; Vaz et al. 2011; Heleno et al. 2012). The presence of some flavonoids such quercetin, rutin and chrysin (Valentão et al. 2005; Ribeiro et al. 2006; Kim et al. 2008; Jayakumar et al. 2009; Yaltirak et al. 2009) and tannins like ellagic acid (Ribeiro et al. 2007) were reported (Table 1).

In vitro and epidemiologic studies suggest that consumption of foods rich in phenolic compounds might significantly decrease the risk of some health problems due to their antioxidant, antimutagenic, anti-inflammatory and antibacterial properties (Surh 2002; Albayrak et al. 2010). Nowadays, the evidence that the increasing number of microorganisms resistant to the available antibiotics is an emergent problem and subject for researchers and clinicians from all over the world. In general, it can be observed that the treatment of virus, bacteria, fungi and protozoa with the existent drugs is increasingly difficult. To overlap the disadvantages of the available antimicrobial drugs, other drugs with new mechanisms of action should be developed (Khalafi-Nezhad et al. 2005). 
Although the antimicrobial activity of extracts from several mushroom species have been reported (Barros et al. 2007; Quereshi et al. 2010; Ozen et al. 2011; Alves et al., 2012), studies with the individual compounds present in that extracts are scarce, being mainly related to phenolic compounds identified in plant sources (Kuete et al. 2009; Orhan et al. 2010; Lou et al. 2012).

Therefore, the aim of the present study was to evaluate the antimicrobial activity of most relevant compounds identified and quantified in mushroom species from all over the world. Furthermore, a structure activity relationship (SAR) analysis and molecular docking studies against Penicillin Binding Protein 2a (PBP2a) were performed, in order to give insights in the mechanism of action of potential antimicrobial drugs for resistant microorganisms. Molecular docking is an in silico tool that predicts how a ligand (substrate or drug candidate) interacts with a receptor (e.g. proteins involved in several biological processes) and has been successfully applied in several therapeutic programs at the lead discovery stage (Ghosh et al. 2006).

\section{Materials and Methods}

\section{Standards and reagents}

The culture media Muller Hinton broth (MHB) and Wilkins-Chalgren Broth (WCB) were obtained from Biomerieux (Marcy 1' Etoile, France), respectively. The dye $p$ iodonitrotetrazolium chloride (INT) was purchased from sigma-Aldrich (Spruce Street;

St. Louis, USA) to be used as microbial growth indicator. Water was treated in a MilliQ water purification system (TGI Pure Water Systems, USA) before use.

\section{Phenolic compounds}


Sixteen phenolic compounds (phenolic acids, flavonoids and tannins) already identified in tens of different wild mushroom species by our research group and by others (Table 1), were submitted to antimicrobial activity evaluation against Gram positive and Gram negative bacteria clinical isolates. Compounds were dissolved in water or in water with $1 \%$ DMSO (for flavonoids and tannins), at a concentration of $10 \mathrm{mg} / \mathrm{mL}$, and stored at $20^{\circ} \mathrm{C}$ for further use (up to 1 week).

\section{Microorganisms and culture media}

The microorganisms used were clinical isolates from patients hospitalized in various departments of the Hospital Center of Trás-os-Montes e Alto Douro - Chaves, Portugal. Six Gram positive bacteria (methicillin-susceptible Staphylococcus aureus (MSSA) and methicillin-resistant Staphylococcus aureus (MRSA) isolated from wound exudates, Staphylococcus epidermidis, Enterococcus faecalis and Listeria monocytogenes isolated from blood culture, and Streptococcus agalactiae isolated from vaginal swab and five Gram negative bacteria (Escherichia coli, Proteus mirabilis and Morganella morganii, isolated from urine, Pasteurella multocida isolated from synozial fluid and Neisseria gonorrhoeae isolated from urethral exudate) were used to screen the antimicrobial activity of the selected phenolic compounds. Escherichia coli showed resistance to fluoroquinolones (levofloxacin and ciprofloxacin) and ampicillin, being intermedia for amoxicillin/clavulanic acid; Proteus mirabilis was resistant to nalidixic acid, levofloxacin, nitrofurantoin, fosfomycin and trimethoprim/sulfasoxazole, and intermediate to gentamicin; Morganella morganii showed resistance to ampicillin, amoxicillin/clavulanic acid, cephalothin, cefazolin, cefuroxime, nitrofurantoin, fosfomycin and trimethoprim /sulfasoxazole; MSSA was only resistant to penicillin and 
ampicillin, while MRSA was resistant to oxacillin, levofloxacin and ciprofloxacin; Staphylococcus epidermidis showed resistance to oxacillin and erythromycin.

All strains were identified using the MicroScan automated methodology - Siemens. Muller Hinton broth (MHB) and Wilkins-Chalgren Broth (WCB) were used for determination of Minimum Inhibitory Concentration (MIC, lowest concentration of the phenolic compound able to completely inhibit bacterial growth).

\section{Test assays for antimicrobial activity}

MIC determinations were performed by the microdilution method and the rapid $p$ iodonitrotetrazolium chloride (INT) colorimetric assay following the methodology suggested by Kuete et al. (2011) with some modifications.

Initially, $50 \mu \mathrm{L}$ of each phenolic compound solution $(1 \mathrm{mg} / \mathrm{mL})$ filter sterilized was diluted in $450 \mu \mathrm{L}$ of MHB for all microorganisms except for Neisseria gonorheia where WCB was used (also with final concentration of $1 \mathrm{mg} / \mathrm{mL}$ ) and then, $200 \mu \mathrm{L}$ of this solution was added in each well (96-well microplate). Titrations (eight different final concentrations) were carried out over the wells containing $100 \mu \mathrm{L}$ of MHB or WCB and afterwards, $10 \mu \mathrm{L}$ of inoculum $\left(1 \times 10^{8} \mathrm{cfu} / \mathrm{mL}\right)$ were added to all the wells.

Two negative (one with MHB or WCB and the other with the phenolic compound) and one positive (with MHB or WCB and the inoculum) controls were performed. The plates were incubated at $37^{\circ} \mathrm{C}$, for $24 \mathrm{~h}$, in an oven (Jouan, Berlin, Germany) or with humidified atmosphere containing $10 \% \mathrm{CO}_{2}$ (NuAire, Plymouth, USA), in the case of Neisseria gonorrhoeae.

The MIC of the samples were detected following addition of INT $(0.2 \mathrm{mg} / \mathrm{mL}, 40 \mu \mathrm{L})$ and incubation at $37^{\circ} \mathrm{C}$ for $30 \mathrm{~min}$. Viable microorganisms reduced the yellow dye to a pink colour. MIC was defined as the lowest phenolic compound concentration that 
prevented this change and exhibited complete inhibition of bacterial growth. All the assays were carried out in duplicate.

\section{Compounds and protein structure preparation}

$\mathrm{ACD} /$ ChemSketch Freeware 12.0 software was used to design 2D structure of the compounds. The software VegaZZ 2.3.1 (Pedretti et al. 2004) was then used to convert all compounds from 2D to 3D structures. AutoDockTools 1.5.2 (ADT) (Sanner 2005) was used to merge nonpolar hydrogens, add Gasteiger charges, and set up rotatable bonds through AutoTors.

The crystal structure of PBP2a (Penicillin Binding Protein 2a) was obtained from the Protein Data Bank (PDB): 1VQQ (PDB entry) (Lim and Strynadka 2002). The software AutoDockTools was also used to assign polar hydrogens, add gasteiger charges and save the protein structure in PDBQT file format. AutoGrid4 (Morris et al. 2009) was used to create affinity grid maps for all the atoms on the protein and phenolic compounds used.

\section{Molecular docking}

AutoDock4 (version 4.2) with the Lamarckian genetic algorithm was used to perform the docking studies. Docking parameters selected for AutoDock4 runs were as follows: 100 docking runs, population size of 200 , random starting position and conformation, translation step ranges of $2.0 \AA$, mutation rate of 0.02 , crossover rate of 0.8 , local search rate of 0.06 , and 2.5 million energy evaluations. Docked conformations were clustered using a tolerance of $2.0 \AA$ RMSD (Root Mean Square Deviation). The molecular docking experiments were performed on a dedicated cluster of 64 Core AMD $2.0 \mathrm{GHz}$, running on CentOS and using MOLA, a custom designed software for virtual screening 
using AutoDock (Abreu et al. 2010). All figures with structure representations were produced using PyMOL (The PyMOL Molecular Graphics System, Version 1.3, Schrödinger, LLC. Available at: (http://www.pymol.org/).

\section{Results}

Table 1 presents phenolic compounds that have been identified in different mushroom species from several countries, where it can be observed that different compounds were detected in the same species. Several external factors have been pointed to explain this fact, such as the heterogeneous enzymatic and oxidative decomposition after collection, different stress conditions associated to each sample, and even dissimilar methodologies applied to phenolic compounds extraction (Oke and Aslim 2011; Vaz et al. 2011).

These compounds are well known for their antioxidant properties (Puttaraju et al. 2006; Ribeiro et al. 2007; Kim et al. 2008), but they also revealed antimicrobial activity (Barros et al. 2007; Quereshi et al. 2010; Schwan et al. 2010; Ozen et al. 2011) emerging with potential against multiresistances. Their increasing prevalence is one of the major challenges for the healthcare systems worldwide. Antibiotic resistant infections are associated with a 1.3 to 2-fold increase in mortality compared to antibiotic susceptible infections (Cosgrove and Carmeli 2003). Moreover, antibiotic resistance imposes enormous health expenditure due to the higher treatment costs and longer hospital stays. In addition, the development of new generations of antibiotic drugs is stalling.

In the present study, in the range of tested concentrations $(0.78-1000 \mu \mathrm{g} / \mathrm{mL}), 2,4-$ dihydroxybenzoic, protocatechuic, vanillic and $p$-coumaric acids showed antibacterial activity $(\mathrm{MIC}=1 \mathrm{mg} / \mathrm{mL})$ against Escherichia coli, Pasteurella multocida and Neisseria gonorrhoeae (Table 2). It should be highlighted that the Escherichia coli isolate used 
herein shows resistance to fluoroquinolones (levofloxacin and ciprofloxacin) and ampicillin, being intermedia for amoxicilin/clavulanic acid. Kuete et al. (2009) reported a $\mathrm{MIC}=78 \mu \mathrm{g} / \mathrm{mL}$ for protocatechuic acid isolated from Ficus ovata against Escherichia coli ( $\beta$ - lactamases positive). The observed difference in MIC values could be related to the use of strains with different susceptibility profiles. Escherichia coli resistance to fluoroquinolones and cephalosporins has drastically increased in the last decade (Rogers et al. 2011), the mentioned phenolic acids could be an option against this bacteria. Recently, Lou et al. (2012) also reported the antimicrobial activity of $p$-coumaric acid $(\mathrm{MIC}=80 \mu \mathrm{g} / \mathrm{L})$ against Escherichia coli, but also against other Gram negative bacteria such as Salmonella typhimurium and Shigella dysenteriae; this compound changes the permeability of the cell membrane and has the capacity to bind DNA inhibiting cell function. Other authors (Teke et al. 2011) described the antimicrobial activity of vanillic acid against Escherichia coli and Proteus mirabilis, which is in agreement with the results reported herein. Moreover, the Proteus mirabilis strain used in the present study shows resistance to nalidixic acid, ciprofloxacin, nitrofurantoin, fosfomycin and trimethoprim/sulfasoxazole, being intermedia for gentamicin. Nevertheless, it should be highlighted that the strains used herein have different antibiotic resistance profiles, while the ones used in the mentioned study did not revealed relevant resistances; this important feature could be related to the differences observed in MIC values.

Despite the absence of reports regarding the presence of 2,4-dihydroxybenzoic acid in mushrooms and its antimicrobial activity, due to the chemical similarity with other phenolic acids mentioned as antimicrobial compounds, we decided to test it and, as far as we know this is the first report on its activity against Gram negative bacteria.

Gallic acid, ferulic acid and quercetin exhibited activity only against Pasteurella multocida and Neisseria gonorrhoeae, and the latter was mainly sensible to quercetin 
(MIC=0.5 mg/mL; Table 2). According to WHO report published in 2001, more than six million cases of gonorrhea (infection caused by Neisseria gonorrhoeae) occur in each year, and with increasing levels, mostly in developing countries; furthermore, there is an emergent resistance of this bacteria to the antimicrobial agents used in gonorrhea treatment. Therefore, the mentioned phenolic compounds could be an alternative to be explored for the control of this infection. Studies evaluating the antibacterial activity of mushroom extracts or isolated compounds against Neisseria gonorrhoeae are scarce, so it is important to clarify their mechanism of action upon this microorganism as also in other Gram negative cocci.

Although no activity was observed for rutin against the tested Gram negative bacteria (Table 2), other authors (Orhan et al. 2010) reported antimicrobial activity of this compound against different strains of Gram negative bacilli, such as Escherichia coli, Proteus mirabilis, Klebsiella pneumoniae, Pseudomonas aeruginosa and Acinetobacter baumannii.

Once more, 2,4-dihydroxybenzoic and protocatechuic acid were the phenolic compounds with higher activity against the majority of Gram positive bacteria (Table 3). Protocatechuic acid showed a MIC of $1 \mathrm{mg} / \mathrm{mL}$ for MSSA and MRSA, as also for Listeria monocytogenes and Streptococcus agalactiae. Other studies reported the antimicrobial activity of this compound against Staphylococcus aureus and with lower concentrations ( $\mathrm{MIC}=156 \mu \mathrm{g} / \mathrm{mL}$; Kuete et al. 2009). Once more, the strain used herein was resistant to oxacillin and to both fluoroquinolones (ciprofloxacin and levofloxacin), which could be responsible for the higher MIC value observed in comparison to the mentioned study.

Regarding Staphylococcus, ferulic and caffeic acids were the only phenolic compounds inhibiting Staphylococcus aureus, MRSA and Staphylococcus epidermidis. 
Nevertheless, other authors reported antimicrobial activity of $p$-coumaric acid, quercetin and rutin against Staphylococcus aureus (Kuete et al. 2009; Orhan et al. 2010; Lou et al. 2012). The absence of antimicrobial activity observed in the present study could be related to the different dissolution solvent used, water, and not ethanol:hexane and Tween 80 as used by the mentioned authors. Nevertheless, some of those solvents might have some inherent toxicity and should be carefully used.

Syringic and ellagic acids showed a MIC of $0.5 \mathrm{mg} / \mathrm{mL}$ against Listeria monocytogenes (Table 3). Cinnamic acid seemed to be the most active upon Steptococcus agalactiae (CMI $0.5 \mathrm{mg} / \mathrm{mL}$ ) Among all the tested phenolic compounds, only 2,4dihydroxybenzoic acid inhibited Enterococcus faecalis (MIC=1 mg/mL); nonetheless, other authors described antimicrobial activity of rutin $(\mathrm{MIC}=128 \mathrm{mg} / \mathrm{mL}$ ), protocatechuic acid $(\mathrm{MIC}=39 \mu \mathrm{g} / \mathrm{mL})$ and vanillic acid (zone of inhibition $16 \mathrm{~mm}$ ) (Kuete et al. 2009; Orhan et al. 2010; Teke et al. 2011). Isolates of Enterococcus faecalis and Enterococcus faecium are the third- to fourth-most prevalent nosocomial pathogen worldwide; acquired resistance, most prominently to penicilin/ampicillin, aminoglycosides (high-level resistance) and glycopeptides are reported in an increasing number of isolates, and the therapeutic spectrum in these cases is limited. Therefore, therapeutic alternatives to treat infections with multi- and vancomycin-resistant enterococci (VRE) are restricted to antibiotics introduced recently into clinical practice such as quinupristin/dalfopristin, linezolid, tigecyclin and daptomycin. However, these drugs are only approved for certain indications and resistance has already been reported (Montero et al. 2008; Werner et al. 2008), which emphasizes the importance of the discovery of new alternative drugs.

It should be notice that the differences among the results reported by several authors could be related to the use of strains with different resistance profiles, but also to 
different methodologies used including different solvents for compound solution preparation or different techniques to determine MICs. In the present study, water was chosen for being the most innocuous solvent; however in the case of flavonoids and tannins water with $1 \%$ DMSO was used to assure the total solubility of the compounds. MRSA has been indicated as one of the major causes of nosocomial infections and its increasing prevalence has been observed in the last decade. Furthermore, the treatment of MRSA infections is difficult due to the restrict spectra of efficient antibiotics (Chambers et al. 2001). The obtained data in the present study (Table 3) show that phenolic compounds inhibited more MRSA than methicillin sensible Staphylococcus aureus. MRSA was inhibited by 2,4-dihydroxybenzoic, vanillic, syringic (MICs=0.5 $\mathrm{mg} / \mathrm{mL})$ and $p$-coumaric $(\mathrm{MIC}=1 \mathrm{mg} / \mathrm{mL})$ acids, while these compounds at the same concentrations had no inhibitory effects against methicillin sensible Staphylococcus aureus. Ferulic acid inhibited both MRSA and methicillin sensible Staphylococcus aureus, but in a lower concentration for MRSA (Table 3).

\section{Discussion}

Regarding these results, it is interesting to notice that the two Staphylococcus aureus tested showed different susceptibility toward the compounds tested, possibly explained by the different resistance mechanisms exhibited by each strain. To understand theses differential effects, a structure-activity relationship (SAR) study was carried by analysing the different chemical structure patterns of the evaluated compounds.

Only phenolic acids (benzoic and cinnamic acid derivatives) showed activity, highlighting the importance of the carboxylic group in the molecule structure (proton acceptor). Furthermore, all the compounds with anti-MRSA activity have $\mathrm{OH}$ (proton donor) and $\mathrm{OCH}_{3}$ (proton acceptor) groups in the para and meta positions of the 
benzene ring, respectively (Table 4).In the absence of $\mathrm{OCH}_{3}$ group in the meta position ( $p$-coumaric acid), the activity decreased. Nevertheless, the absence of the mentioned group in the structure of 2,4-dihydroxybenzoic acid seemed to be overlapped by the $\mathrm{OH}$ substitution in ortho position of the benzene ring. Only $\mathrm{OCH}_{3}$ (proton acceptor) or $\mathrm{H}$ in position 5 of the benzene ring allowed anti-MRSA activity, since when $\mathrm{OH}$ is presented in that position the activity disappears (see the examples of protocatechuic and gallic acids in Table 4).

MRSA is resistant to all $\beta$-lactam antibiotics and this ability is due to the acquisition of mecA gene (Lowy 2003). This gene encodes the PBP2a protein and when it is challenged by $\beta$-lactams, MRSA will use the transpeptidase functionality of PBP2a to synthesize the cell wall (Wilke et al. 2005).

Since the major difference between MSSA and MRSA is mecA, studies of molecular docking were performed using $3 \mathrm{D}$ crystal structure of PBP2a (PDB:1QVV) as target to understand the inhibition mechanism of the phenolic compounds with activity against MRSA. The docking results revealed a superimposition of the docking poses for the three benzoic acid derivatives (vanillic, 2,4-dihydroxybenzoic and syringic acids) (Figure 1).

The binding pose shows several hydrogen bonds (H-bonds) that validate SAR analysis described above. The carboxylic group is stabilized by H-bonds with the amino $\left(\mathrm{NH}_{2}\right)$ group of LYS406 side chain, the hydroxyl $(\mathrm{OH})$ group of SER403 side chain and the carbaxamide $\left(\mathrm{NH}_{2} \mathrm{CO}\right)$ group of ASP464 side chain. Furthermore, $\mathrm{OH}$ in the para position of the benzene ring, which contributes to the anti-MRSA activity of the compounds, establishes a hydrogen bond with Serine (SER461) carbonyl group of the peptidic bond. The $\mathrm{OCH}_{3}$ group in the meta position of the benzene ring (as in vanillic and syringic acids) is stabilized by a hydrogen bond with Glutamate (GLU447) amine 
group of the peptidic bond. The $\mathrm{OH}$ in meta position of the benzene ring (as in 2,4dihydroxybenzoic acid) is stabilized by a hydrogen bond with Serine (SER462) carbonyl group of the peptidic bond.

Overall, 2,4-dihydroxybenzoic, protocatechuic, vanillic and $p$-coumaric acids were the compounds that showed higher antimicrobial activity against Gram positive and negative bacteria. Cinnamic acid derivatives revealed higher antimicrobial activity against Gram positive and negative coccus.

The presence of carboxylic acid $(\mathrm{COOH})$, two hydroxyl $(\mathrm{OH})$ groups in para and ortho positions of the benzene ring, as also a methoxyl $\left(\mathrm{OCH}_{3}\right)$ group in the meta position seems to play an important role in the studied phenolic compounds anti-MRSA activity. The docking studies provided strong evidence that the molecular basis for this activity is probably as PBP2a inhibitors. The mentioned compounds could be a solution for multiresistance problem, but their mechanism of action in different microorganisms should be better understood.

\section{Acknowledgements}

The authors are grateful to Fundação para a Ciência e a Tecnologia (FCT, Portugal) and COMPETE/QREN/EU for financial support to this work (research project PTDC/AGRALI/110062/2009) and to CIMO (strategic project PEst-OE/AGR/UI0690/2011) and to PEst-OE/EQB/LA0016/2011. They also thank to CHTAD - Hospital Center of Trás-osMontes e Alto Douro and Siemens for all the support.

\section{References}


Albayrak, S., Aksoy, A., Sagdic, O., Hamzaoglu, E. (2010). Compositions, antioxidant and antimicrobial activities of Helichrysum (Asteraceae) species collected from Turkey. Food Chem 119, 114-122.

Alves, M.J., Ferreira, I.C.F.R., Martins, A., Pintado, M. (2012). Antimicrobial activity of wild mushrooms extracts against clinical isolates resistant to different antibiotics. J Apl Microbiol 113, 466-475.

Barros, L., Calhelha, R.C., Vaz, J.A., Ferreira, I.C.F.R., Baptista, P., Estevinho, L.M. (2007). Antimicrobial activity and bioactive compounds of Portuguese wild edible mushrooms methanolic extracts. Eur Food Res Technol 225, 151-156.

Barros, L., Dueñas, M., Ferreira, I.C.F.R., Baptista, P., Santos- Buelga, C. (2009). Phenolic acids determination by HPLC-DAD-ESI/MS in sixteen different Portuguese wild mushrooms species. Food Chem Toxicol 47, 1076-1079.

Chambers, H.F. (2001). The changing epidemiology of Staphylococcus aureus? Emerg Infect Dis 7, 178-182.

Cosgrove, S.E., Carmeli, Y. (2003). The impact of antimicrobial resistance on health and economic outcomes. Clin Infect Dis 36, 1433-1437.

Ghosh, S., Nie, A.H., An, J., Huang, Z.W. (2006). Structure-based virtual screening of chemical libraries for drug discovery. Curr Opin Chem Biol 10, 194-202.

Heleno, S.A., Barros, L., Sousa, M.J., Martins, A., Santos-Buelga, C., Ferreira, I.C.F.R. (2011). Targeted metabolites analysis in wild Boletus species. LWT 44, 13431348.

Heleno, S.A., Barros, L., Martins, A., Queiroz, M.J.R.P., Santos-Buelga, C., Ferreira, I.C.F.R. (2012). Fruiting body spores and in vitro produced mycelium of Ganoderma lucidum from Northeast Portugal: A comparative study of the 
antioxidant potential of phenolic and polysaccharidic extracts. Food Res Int 46, 135-140.

Jayakumar, T., Thomas, P.A. (2009). Geraldine P. In-vitro antioxidant activities of an ethanolic extract of the oyster mushroom, Pleurotus ostreatus. Innovat Food Sci Emerg Technol 10, 228-234.

Khalafi-Nezhad, A., Rad, M.N.S., Mohabatkar, H., Asrari, Z., Hemmateenejad, B. (2005). Design, synthesis, antibacterial and QSAR studies of benzimidazole and imidazole chloroaryloxyalkyl derivatives. Bioorg Med Chem 13, 1931-1938.

Kim, M.Y., Seguin, P., Ahn, J.K., Kim, J.J., Chun, S.C., Kim, E.H., Seo, S.H., Kang, E.Y., Kim, S.L., Park, Y.J., Ro, H.M., Chung, I.M. (2008). Phenolic compound concentration and antioxidant activities of edible and medicinal mushrooms from Korea. J Agric Food Chem 56, 7265-7270.

Kuete, V., Ango, P.Y., Fotso, G.W., Kapche, G.D., Dzoyem, J.P., Wouking, A.G., Ngadjui, B.T., Abegaz, B.M. (2011). Antimicrobial activities of the methanol extract and compounds from Artocarpus communis (Moraceae). BMC Complement Altern Med 25, 11-42.

Kuete, V., Nana, F., Ngameni, B., Mbaveng, A.T., Keumedjio, F., Ngadjui, B.T. (2009). Antimicrobial activity of the crude extract, fractions and compounds from stem bark of Ficus ovata (Moraceae). J Ethnopharmacol 124, 556-561.

Lim, D., Strynadka, N.C.J. (2002). Structural basis for the beta lactam resistance of PBP2a from methicillin-resistant Staphylococcus aureus. Nat Struct Biol 9, 870876.

Lou, Z., Wang, H., Rao, S., Sun, J., Ma, C., Li, J.(2012). p-Coumaric acid kills bacteria through dual damage mechanisms. Food Control 25, 550-554. 
Lowy, F.D. (2003). Antimicrobial resistance: the example of Staphylococcus aureus. J Clin Invest 111, 1265-1273.

Mattila, P., Konko, K., Eurola, M., Pihlava, J.M., Astola, J., Vahteristo, L., Hietaniemi, V., Kumpulainen, J., Valtonen, M., Piironen, V. (2001). Contents of vitamins, mineral elements, and some phenolic compounds in cultivated mushrooms. J Agric Food Chem 49, 2343-2348.

Montero, C.I., Stock, F., Murray, P.R. (2008). Mechanisms of resistance to daptomycin in Enterococcus faecium. Antimicrob Agent Chemother 52, 1167-1170.

Morris, G.M., Huey, R., Lindstrom, W., Sanner, M.F., Belew, R.K., Goodsell, D.S., Olson, A.J. (2009). AutoDock4 and AutoDockTools4: Automated docking with selective receptor flexibility. J Comput Chem 30, 2785-2791.

Oke F., Aslim, B. (2011). Protective effect of two edible mushrooms against oxidative cell damage and their phenolic composition. Food Chem 128, 613-619.

Orhan, D.D., Özçelik, B., Özgen, S., Ergun, F. (2010). Antibacterial, antifungal, and antiviral activities of some flavonoids. Microbiol Res 165, 496-500.

Ozen, T., Darcan, C., Aktop, O., Turkekul, I. (2011). Screening of antioxidant, antimicrobial activities and chemical contents of edible mushrooms wildly grown in the Black Sea region of Turkey. Comb Chem High Throughput Screen 14, 7284.

Palacios, I., Lozano, M., Moro, C., D’Arrigo, M., Rostagno, M.A., Martínez, J.A., García-Lafuente, A., Guillamón, E., Villares, A. (2011). Antioxidant properties of phenolic compounds occurring in edible mushrooms. Food Chem 128, 674-678.

Puttaraju, N.G., Venkateshaiah, S.U., Dharmesh, S.M., Urs, S.M., Somasundaram, R. (2006). Antioxidant activity of indigenous edible mushrooms. J Agric Food Chem 54, 9764-9772. 
Quereshi, S., Pandey, A.K., Sandhu, S.S. (2010). Evaluation of antibacterial activity of different Ganoderma lucidum extracts. J Sci Res 3, 9-13.

Pedretti, A., Villa, L., Vistoli, G. (2004). VEGA - An open platform to develop chemobio-informatics applications, using plug-in architecture and script programming. J Comp-Aid Mol Design 18, 167-173.

Reis, F.S., Heleno, S.A., Barros, L., Sousa, M.J., Martins, A., Santos-Buelga, C., Ferreira, I.C.F.R. (2011). Toward the antioxidant and chemical characterization of mycorrhizal mushrooms from Northeast Portugal. J Food Sci 76, 824-830.

Ribeiro, B., Rangel, J., Valentão, P., Baptista, P., Seabra, R.M., Andrade, P.B. (2006). Contents of carboxylic acids and two phenolics and antioxidant activity of dried Portuguese wild edible mushrooms. J Agric Food Chem 54, 8530-8537.

Ribeiro, B., Valentão, P., Baptista, P., Seabra, R.M., Andrade, P.B. (2007). Phenolic compounds, organic acids profiles and antioxidative properties of beefsteak fungus (Fistulina hepatica). Food Chem Toxicol 45, 1805-1813.

Rogers, B.A., Sidjabat, H.E., Paterson, D.L. (2011). Escherichia coli O25b-ST131: a pandemic, multiresistant, community-associated strain. J Antimicrob Chemother 66, 1-14.

Sanner, M.F. (2005). A component-based software environment for visualizing large macromolecular assemblies. Structure 13, 447-462.

Surh, Y.J. (2002). Anti-tumor promoting potential of selected spice ingredients with antioxidative and anti-inflammatory activities: a short review. Food Chem Toxicol 40, 1091-1097.

Teke, G.N., Kuiate, J.-R., Kueté, V., Teponno, R.B., Tapondjou, L.A., Tane, P., Giacinti, G., Vilarem, G. (2011). Bio-guided isolation of potential antimicrobial 
and antioxidant agents from the stem bark of Trilepisium madagascariense. South Afr J Botany 77, 319-327.

Valentão, P., Andrade, P.B., Rangel, J., Ribeiro, B., Silva, B.M., Baptista, P., Seabra, R.M. (2005). Effect of the conservation procedure on the contents of phenolic compounds and organic acids in Chanterelle (Cantharellus cibarius) mushroom. J Agric Food Chem 53, 4925-4931.

Vaz, J.A., Barros, L., Martins, A., Morais, J.S., Vasconcelos, M.H., Ferreira, I.C.F.R. (2011a). Phenolic profile of seventeen Portuguese wild mushrooms. LWT 44, 343-346.

Vaz, J.A., Barros, L., Martins, A., Santos-Buelga, C., Vasconcelos, M.H., Ferreira, I.C.F.R. (2011b). Chemical composition of wild edible mushrooms and antioxidant properties of their water soluble polysaccharidic and ethanolic fractions. Food Chem. 126, 610-616.

Werner, G., Gfrörer, S., Fleige, C., Witte, W., Klare, I. (2008). Tigecycline-resistant Enterococcus faecalis strain isolated from a German ICU patient. J Antimicrob Chemother 61, 1182-1183.

WHO. (2001). Global Prevalence and Incidence of Selected Curable Sexually Transmitted Diseases: Overview and Estimates.

Wilke, M.S., Lovering, A.L., Strynadka, N.C.J. (2005). $\beta$-Lactam antibiotic resistance : a current structural perspective. Curr Op Microbiol 8, 525-533.

Yaltirak, T., Aslim, B., Ozturk, S., Alli, H. (2009). Antimicrobial and antioxidant activities of Russula delica Fr. Food Chem Toxicol 47, 2052- 2056. 
Table 1. Phenolic compounds identified in wild mushrooms and submitted to antimicrobial activity evaluation.

\begin{tabular}{|c|c|c|c|}
\hline Phenolic compounds & Mushroom species & Country & References \\
\hline \multicolumn{4}{|c|}{ Phenolic acids: benzoic acid derivatives } \\
\hline$p$ - Hydroxybenzoic acid & $\begin{array}{l}\text { Agaricus arvensis, Agaricus bisporus, Agaricus romagnesii, Agaricus silvicola, } \\
\text { Amanita caesarea, Amanita muscaria, Amanita pantherina, Amanita rubescens, Armillaria } \\
\text { mellea, Auricularia auricula-judae, Boletus aereus, Boletus edulis, Boletus reticulatus, } \\
\text { Boletus rhodoxanthus, Boletus satanas, Calocybe gambosa, Cantharellus cibarius, } \\
\text { Chroogomphus fulmineus, Citocybe odora, Coprinus comatus, Cortinarius anomalus, } \\
\text { Cortinarius collinitus, Cortinarius violaceus, Craterellus cornocopioides, Fistulina } \\
\text { hepática, Ganoderma lucidum, Hygrophorus marzuolus, Hygrophorus olivaceo-albus, } \\
\text { Ionotus obliquu, Lactarius deliciosus, Lactarius salmonicolor, Lactarius volemus, Lepista } \\
\text { nuda, Lentinus edodes, Lycoperdon molle, Phellinus linteus, Pleurotus eryngii, Pleurotus } \\
\text { ostreatus Ramaria botrytis, Russula cyanoxantha, Sarcodon imbricatus, Sparassis crispa, } \\
\text { Suillus granulatus, Suillus collinitus, Suillus mediterraneensis, Tricholoma acerbum, } \\
\text { Tricholoma equestre, Tricholoma sulphureum }\end{array}$ & $\begin{array}{l}\text { Finland, Korea, } \\
\text { Portugal, Spain, } \\
\text { Turkea }\end{array}$ & $\begin{array}{l}\text { Mattila et al. 2000; } \\
\text { Ribeiro et al. } 2006, \\
\text { 2007; Kim et al. 2008; } \\
\text { Barros et al. 2009; } \\
\text { Heleno et al. 2011; } \\
\text { 2012; Oke et al. 2011; } \\
\text { Palacios et al. 2011; } \\
\text { Reis et al. 2011; } \\
\text { Vaz et al. 2011a, 2011b }\end{array}$ \\
\hline Protocatechuic acid & $\begin{array}{l}\text { Agaricus bisporus, Agaricus blazei, Amanita caesarea, Amanita pantherina, Auricularia } \\
\text { polytricha, Boletus edulis, Boletus rhodoxanthus, Boletus satanas, Cantharellus cibarius, } \\
\text { Cantherallus clavatus, Calocybe gambosa, Chroogomphus fulmineus, cortinarius } \\
\text { anomalus, Craterellus cornocopioides, Fistulina hepática, Flammulina velutipes, } \\
\text { Ganoderma lucidum, Helvella crispa, Hygrophorus agathosmus, Hygrophorus marzuolus, } \\
\text { Hydnum repandum, Ionotus obliquus, Lactarius deliciosus, Lactarius sangifluus, } \\
\text { Lentinus edodes, Lentinus squarrulosus, Lentinus sajor caju, Lepista nuda, Macrolepiota } \\
\text { procera, Morchella anguiticeps, Morchella conica, , Mycena haematopus, Pleurotus } \\
\text { djamor, Pleurotus eryngii, Phellinus linteus, Pleurotus ostreatus, Pleurotus sajor-caju, } \\
\text { Ramaria botrytis, Russula brevepis, Sparassis crispa, Suillus collinitus, Suillus } \\
\text { mediterraneensis, Termitomyces heimii, Termitomyces microcarpus, Termitomyces } \\
\text { mummiformis, Termitomyces shimperi, Termitomyces tylerance }\end{array}$ & $\begin{array}{l}\text { Finland, India, } \\
\text { Korea, Portugal, } \\
\text { Spain }\end{array}$ & $\begin{array}{l}\text { Puttaraju et al. 2006; } \\
\text { Kim et al. 2008; Barros } \\
\text { et al. 2009; Heleno et al. } \\
\text { 2011; Oke et al. 2011; } \\
\text { Palacios et al. 2011; } \\
\text { Reis et al. 2011; Vaz et } \\
\text { al. 2011a }\end{array}$ \\
\hline Gallic acid & $\begin{array}{l}\text { Auricularia auricula-judae, Agaricus bisporus, Agaricus blazei, Auricularia polytricha, } \\
\text { Boletus edulis, Calocybe gambosa, Cantharellus cibarius, Cantherallus clavatus, }\end{array}$ & $\begin{array}{l}\text { India, Korea, } \\
\text { Spain Turkey }\end{array}$ & $\begin{array}{l}\text { Puttaraju et al. 2006; } \\
\text { Kim et al. 2008; }\end{array}$ \\
\hline
\end{tabular}


Craterellus cornocopioides, Flammulina velutipes, Ganoderma lucidum, Geastrum

arinarius, Helvella crispa, Hygrophorus marzuolus, Hydnum repandum, Ionotus obliquus, Lactarius deliciosus, Lactarius sangifluus, Lentinus edodes, Lentinus sajor caju, Lentinus squarrulosus, Macrolepiota procera, Morchella anguiticeps, Morchella conica,

Pleurotus djamor, Pleurotus eryngii, Pleurotus ostreatus, Phellinus linteus, Pleurotus sajor-caju, Russula brevepis, Russula delica, Sparassis crispa, Termitomyces heimii,

Termitomyces microcarpus, Termitomyces mummiformis, Termitomyces shimperi, Termitomyces tylerance

\begin{tabular}{|c|c|}
\hline Vanillic acid & $\begin{array}{l}\text { Auricularia auricula-judae, Auricularia polytricha, Cantherallus clavatus, Helvella crispa, } \\
\text { Hydnum repandum, Lactarius sangifluus, Lentinus squarrulosus, Lentinus sajor caju, } \\
\text { Lycoperdon molle, Macrolepiota procera, Morchella conica, Pleurotus sajorcaju, } \\
\text { Pleurotus djamor, Pleurotus eryngii, Russula brevepis, Termitomyces heimii, Termitomyces } \\
\text { microcarpus, Termitomyces shimperi, Tricholoma acerbum }\end{array}$ \\
\hline Syringic acid & $\begin{array}{l}\text { Agaricus blazei, Cantherallus clavatus, Auricularia auricula-judae, } \\
\text { Hydnum repandum, Lactarius sangifluus, Lentinus sajor caju, Macrolepiota procera, } \\
\text { Morchella conica, Morchella anguiticeps, Pleurotus eryngii, Pleurotus djamor, Russula } \\
\text { brevepis, Sparassis crispa, Termitomyces mummiformis, Termitomyces tylerance, } \\
\text { Termitomyces microcarpus }\end{array}$ \\
\hline \multicolumn{2}{|c|}{ Cinnamic acid and derivatives } \\
\hline Cinnamic acid & $\begin{array}{l}\text { Agaricus arvensis, Agaricus bisporus, Agaricus blazei Agaricus silvicola, Agaricus } \\
\text { romagnesii, Amanita caesarea, Amanita muscaria, Amanita pantherina, Armillaria mellea, } \\
\text { Boletus aereus, Boletus edulis, Boletus purpureus, Boletus reticulatus, Boletus } \\
\text { rhodoxanthus, Boletus satanas, Calocybe gambosa, Cantharelus cibarius, Cantherallus } \\
\text { clavatus, Chroogomphus fulmineus, Citocybe odora, Coprinus comatus, cortinarius } \\
\text { anomalus, Cortinarius collinitus, Cortinarius violaceus, Fistulina hepática, Ganoderma } \\
\text { lucidum, Hygrophorus agathosmus, Hydnum repandum, Hygrophoropsis aurantiaca, } \\
\text { Hygrophorus olivaceo-albus, Lactarius aurantiacus, Lactarius quietus, Lactarius } \\
\text { salmonicolor, Lactarius sangifluus, Lentinus squarrulosus, Lentinus edodes, Lactarius } \\
\text { volemus, Lycoperdon perlatum, Pleurotus eryngii, } \\
\text { Macrolepiota prócera, Mycena haematopus, Pleurotus sajor-caju, Pleurotus djamor, } \\
\text { Sparassis crispa, Russula caerulea, Russula sardónia, Suillus collinitus, Suillus luteus, } \\
\text { Suillus mediterraneensis, Termitomyces heimii, Termitomyces mummiformis, Termitomyces } \\
\text { shimperi, Tricholoma atrosquamosum, Tricholoma sulphureum, Tricholoma ustale }\end{array}$ \\
\hline
\end{tabular}
shimperi, Tricholoma atrosquamosum, Tricholoma sulphureum, Tricholoma ustale
Yaltirak et al. 2009; Oke et al. 2011; Palacios et al. 2011

India, Portugal, Puttaraju et al. 2006; Turkey Barros et al. 2009; Oke et al. 2011

India, Korea

Puttaraju et al. 2006;

Turkey

al. 2011

Finland, India,

Mattila et al. 2000;

Korea, Portugal,

Turkea Valentão et al. 2005; Puttaraju et al. 2006; Kim et al. 2008; Barros et al. 2009; Heleno et al. 2011, 2012; Oke et al. 2011; Reis et al. 2011; Vaz et al. 2011a, 2011b 
pantherina, Boletus aereus, Boletus edulis, Calocybe gambosa, Cantharellus cibarius,

Chroogomphus fulmineus, Citocybe odora, Coprinus comatus, Cortinarius collinitus,

Fistulina hepática, Ganoderma lucidum, Geastrum arinarius, Hygrophorus agathosmus,

Hygrophorus marzuolus, Lactarius sangifluus, Lentinus sajor caju, Lepista nuda,

Macrolepiota procera, Pleurotus djamor, Pleurotus ostreatus Sparassis crispa,

Termitomyces heimii, Tricholoma atrosquamosum

$o$-Coumaric acid

Caffeic acid

Ionotus obliquus

Auricularia auricula-judae, Agaricus bisporus, Boletus edulis, Calocybe gambosa,

Cantharellus cibarius, Cantherallus clavatus, Fistulina hepática, Flammulina velutipes,

Hygrophorus marzuolus, Lactarius sangifluus, Lactarius deliciosus Lentinus sajor caju,

Lentinus squarrulosus, Morchella anguiticeps, Morchella conica, Macrolepiota procera,

Phellinus linteus, Pleurotus djamor, Pleurotus eryngii,

Russula brevepis, Russula delica, Sparassis crispa, Termitomyces heimii, Termitomyces microcarpus, Termitomyces shimperi Termitomyces tylerance

Ferulic acid

Agaricus bisporus, Cantherallus clavatus, Calocybe gambosa, Cantharellus cibarius,

Craterellus cornocopioides, Flammulina velutipes, Ionotus obliquus, Lactarius deliciosu

Lactarius sangifluus, Lentinus squarrulosus, Morchella conica, Macrolepiota procera,

Pleurotus djamor, Pleurotus ostreatus Pleurotus sajor-caju, Sparassis crispa,

Termitomyces heimii, Termitomyces microcarpus, Termitomyces shimperi

\begin{tabular}{|c|c|c|c|}
\hline 5- $O$-cafeoylquinic acid. & $\begin{array}{l}\text { Agaricus bisporus, Boletus edulis, Calocybe gambosa, Cantharellus cibarius, Flammulina } \\
\text { velutipes, Lactarius deliciosus, Pleurotus ostreatus, Phellinus linteus }\end{array}$ & $\begin{array}{l}\text { Korea, Portugal, } \\
\text { Spain }\end{array}$ & $\begin{array}{l}\text { Valentão et al. } 2005 ; \\
\text { Kim et al. } 2008 ; \\
\text { Palacios } \text { et al. } 2011\end{array}$ \\
\hline \multicolumn{4}{|l|}{ Flavonoids } \\
\hline Quercetin & $\begin{array}{l}\text { Agaricus blazei, Flammulina velutipes, Ganoderma lucidum, Ionotus obliquus, } \\
\text { Sparassis crispa, Suillus luteus, Suillus granulatus }\end{array}$ & Korea, Portugal & $\begin{array}{l}\text { Ribeiro et al. 2006; Kim } \\
\text { et al. } 2008\end{array}$ \\
\hline Rutin & Cantharellus cibarius, Pleurotus ostreatus, Russula delica & India, Turkey & $\begin{array}{l}\text { Valentão et al. } 2005 ; \\
\text { Jayakumar et al. } 2009 ; \\
\text { Yaltirak et al. } 2009\end{array}$ \\
\hline Chrysin & Pleurotus ostreatus & India & Jayakumar et al. 2009 \\
\hline \multicolumn{4}{|l|}{ Tannins } \\
\hline Ellagic acid & Fistulina hepatica & Portugal & Ribeiro et al. 2007 \\
\hline
\end{tabular}

Portugal, Spain Ribeiro et al. 2007; Kim et al. 2008; Barros et al. 2009; Heleno et al.

2011, 2012; Palacios et al. 2011; Reis et al. 2011; Vaz et al. 2011a $2011 b$

Korea Kim et al. 2008

India, Korea, Valentão et al. 2005;

Portugal, Spain, Puttaraju et al. 2006;

Turkey Ribeiro et al. 2007; Kim et al. 2008; Yaltirak et al. 2009; Oke et al.

2011; Palacios et al. 2011

India, Korea,

Puttaraju et al. 2006;

Kim et al. 2008;

Palacios et al. 2011

Spain 
Table 2. MIC values $(\mathrm{mg} / \mathrm{mL})$ of wild mushroom phenolic compounds against clinical isolates of Gram negative bacteria.

\begin{tabular}{llllll}
\hline Phenolic compounds & $\begin{array}{l}\text { Escherichia } \\
\text { coli }\end{array}$ & $\begin{array}{l}\text { Proteus } \\
\text { mirabilis }\end{array}$ & $\begin{array}{l}\text { Morganella } \\
\text { morganni }\end{array}$ & $\begin{array}{l}\text { Pasteurella } \\
\text { multocida }\end{array}$ & $\begin{array}{l}\text { Neisseria } \\
\text { gonorrhoeae }\end{array}$ \\
\hline Benzoic acid derivatives & & & & & \\
$p$-Hydroxybenzoic acid & $>1$ & $>1$ & $>1$ & $>1$ & $>1$ \\
2,4-Dihydroxybenzoic acid & 1 & $>1$ & $>1$ & 1 & 1 \\
Protocatechuic acid & 1 & $>1$ & $>1$ & 1 & 1 \\
Gallic acid & $>1$ & $>1$ & $>1$ & 1 & 1 \\
Vanillic acid & 1 & 1 & $>1$ & 1 & 1 \\
Syringic acid & $>1$ & $>1$ & $>1$ & 1 & $>1$ \\
\hline Cinnamic acid derivatives & & & & & \\
Cinnamic acid & $>1$ & $>1$ & $>1$ & $>1$ & 1 \\
$p$-Coumaric acid & 1 & $>1$ & $>1$ & 1 & 1 \\
$o$-Coumaric acid & $>1$ & $>1$ & $>1$ & $>1$ & $>1$ \\
Caffeic acid & $>1$ & $>1$ & $>1$ & 1 & $>1$ \\
Ferulic acid & $>1$ & $>1$ & $>1$ & 1 & 1 \\
Chlorogenic acid & $>1$ & $>1$ & $>1$ & $>1$ & $>1$ \\
\hline Flavonoids & & & & & \\
Quercetin & $>1$ & $>1$ & $>1$ & 1 & 0,5 \\
Rutin & $>1$ & $>1$ & $>1$ & $>1$ & $>1$ \\
Chrysin & $>1$ & $>1$ & $>1$ & $>1$ & $>1$ \\
\hline Tannins & & & & & $>1$ \\
Ellagic acid & & & $>1$ & 1 & $\mathrm{nt}$ \\
Reference compounds & & $\mathrm{nt}$ & $\mathrm{nt}$ & $\leq 1$ & $\leq 1$ \\
Imipenem & $\mathrm{nt}$ & & & & $\mathrm{nt}$ \\
Ceftriaxon & & & & & \\
\hline & & & & & \\
\hline
\end{tabular}

nt-not tested. 
Table 3. MIC values $(\mathrm{mg} / \mathrm{mL})$ of the wild mushroom phenolic compounds against clinical isolates of Gram positive bacteria.

\begin{tabular}{|c|c|c|c|c|c|c|}
\hline Phenolic compounds & MSSA & MRSA & $\begin{array}{l}\text { Staphylococcus } \\
\text { epidermidis }\end{array}$ & $\begin{array}{l}\text { Enterococcus } \\
\text { faecalis }\end{array}$ & $\begin{array}{l}\text { Listeria } \\
\text { monocytogenes }\end{array}$ & $\begin{array}{l}\text { Streptococcus } \\
\text { agalactiae }\end{array}$ \\
\hline \multicolumn{7}{|l|}{$\begin{array}{l}\text { Benzoic acid } \\
\text { derivatives }\end{array}$} \\
\hline$p$-Hydroxybenzoic acid & $>1$ & $>1$ & $>1$ & $>1$ & $>1$ & $>1$ \\
\hline $\begin{array}{l}\text { 2,4-Dihydroxybenzoic } \\
\text { acid }\end{array}$ & $>1$ & 0.5 & $>1$ & 1 & $>1$ & 1 \\
\hline Protocatechuic acid & 1 & 1 & $>1$ & $>1$ & 1 & 1 \\
\hline Gallic acid & $>1$ & $>1$ & $>1$ & $>1$ & $>1$ & $>1$ \\
\hline Vanillic acid & $>1$ & 0.5 & $>1$ & $>1$ & 1 & 1 \\
\hline Syringic acid & $>1$ & 0.5 & $>1$ & $>1$ & 0.5 & $>1$ \\
\hline \multicolumn{7}{|l|}{$\begin{array}{l}\text { Cinnamic acid } \\
\text { derivatives }\end{array}$} \\
\hline Cinnamic acid & $>1$ & $>1$ & $>1$ & $>1$ & $>1$ & 0.5 \\
\hline$p$-Coumaric acid & $>1$ & 1 & $>1$ & $>1$ & $>1$ & $>1$ \\
\hline$o$-Coumaric acid & $>1$ & $>1$ & $>1$ & $>1$ & $>1$ & 1 \\
\hline Caffeic acid & 1 & 1 & 1 & $>1$ & $>1$ & $>1$ \\
\hline Ferulic acid & 1 & 0.5 & 1 & $>1$ & $>1$ & 1 \\
\hline Chlorogenic acid & $>1$ & $>1$ & $>1$ & $>1$ & 1 & $>1$ \\
\hline \multicolumn{7}{|l|}{ Flavonoids } \\
\hline Quercetin & $>1$ & $>1$ & $>1$ & $>1$ & 1 & $>1$ \\
\hline Rutin & $>1$ & $>1$ & $>1$ & $>1$ & 1 & $>1$ \\
\hline Chrysin & $>1$ & $>1$ & $>1$ & $>1$ & $>1$ & $>1$ \\
\hline \multicolumn{7}{|l|}{ Tannins } \\
\hline Ellagic acid & $>1$ & $>1$ & $>1$ & $>1$ & 0.5 & $>1$ \\
\hline \multicolumn{7}{|l|}{ Reference compounds } \\
\hline Gentamicin & $\leq 1$ & 4 & $\leq 1$ & $\mathrm{nt}$ & $\mathrm{nt}$ & $\mathrm{nt}$ \\
\hline Penicillin & $\mathrm{nt}$ & $\mathrm{nt}$ & $\mathrm{nt}$ & 2 & 0.25 & $\leq 0.03$ \\
\hline
\end{tabular}


Table 4. Phenolic acids identified in mushrooms submitted to structure activity relationship (SAR) analysis.

\begin{tabular}{|c|c|c|c|c|c|}
\hline $\mathrm{R}^{2}$ & \multicolumn{5}{|c|}{ Substitutions } \\
\hline Benzoic acid derivatives & $\mathbf{X}$ & $\mathbf{R}^{1}$ & $\mathbf{R}^{2}$ & $\mathbf{R}^{3}$ & $\mathbf{R}^{4}$ \\
\hline 2,4-Dihydroxybenzoic acid & $\mathrm{COOH}$ & $\mathrm{OH}$ & $\mathrm{H}$ & $\mathrm{OH}$ & $\mathrm{H}$ \\
\hline$p$-Hydroxybenzoic acid & $\mathrm{COOH}$ & $\mathrm{H}$ & $\mathrm{H}$ & $\mathrm{OH}$ & $\mathrm{H}$ \\
\hline Protocatechuic acid & $\mathrm{COOH}$ & $\mathrm{H}$ & $\mathrm{H}$ & $\mathrm{OH}$ & $\mathrm{OH}$ \\
\hline Gallic acid & $\mathrm{COOH}$ & $\mathrm{H}$ & $\mathrm{OH}$ & $\mathrm{OH}$ & $\mathrm{OH}$ \\
\hline Vanillic acid & $\mathrm{COOH}$ & $\mathrm{H}$ & $\mathrm{OCH}_{3}$ & $\mathrm{OH}$ & $\mathrm{H}$ \\
\hline Syringic acid & $\mathrm{COOH}$ & $\mathrm{H}$ & $\mathrm{OCH}_{3}$ & $\mathrm{OH}$ & $\mathrm{OCH}_{3}$ \\
\hline $\mathrm{R}^{4}$ & & Substit & tutions & & \\
\hline Cinnamic acid derivatives & $\mathbf{X}$ & $\mathbf{R}^{1}$ & $\mathbf{R}^{2}$ & $\mathbf{R}^{3}$ & $\mathbf{R}^{4}$ \\
\hline Cinnamic acid & $\mathrm{CHCHCOOH}$ & $\mathrm{H}$ & $\mathrm{H}$ & $\mathrm{H}$ & $\mathrm{H}$ \\
\hline$p$-Coumaric acid & $\mathrm{CHCHCOOH}$ & $\mathrm{H}$ & $\mathrm{H}$ & $\mathrm{OH}$ & $\mathrm{H}$ \\
\hline$o$-Coumaric acid & $\mathrm{CHCHCOOH}$ & $\mathrm{OH}$ & $\mathrm{H}$ & $\mathrm{H}$ & $\mathrm{H}$ \\
\hline Caffeic acid & $\mathrm{CHCHCOOH}$ & $\mathrm{H}$ & $\mathrm{OH}$ & $\mathrm{OH}$ & $\mathrm{H}$ \\
\hline Ferulic acid & $\mathrm{CHCHCOOH}$ & $\mathrm{H}$ & $\mathrm{CH}_{3} \mathrm{O}$ & $\mathrm{OH}$ & $\mathrm{H}$ \\
\hline
\end{tabular}




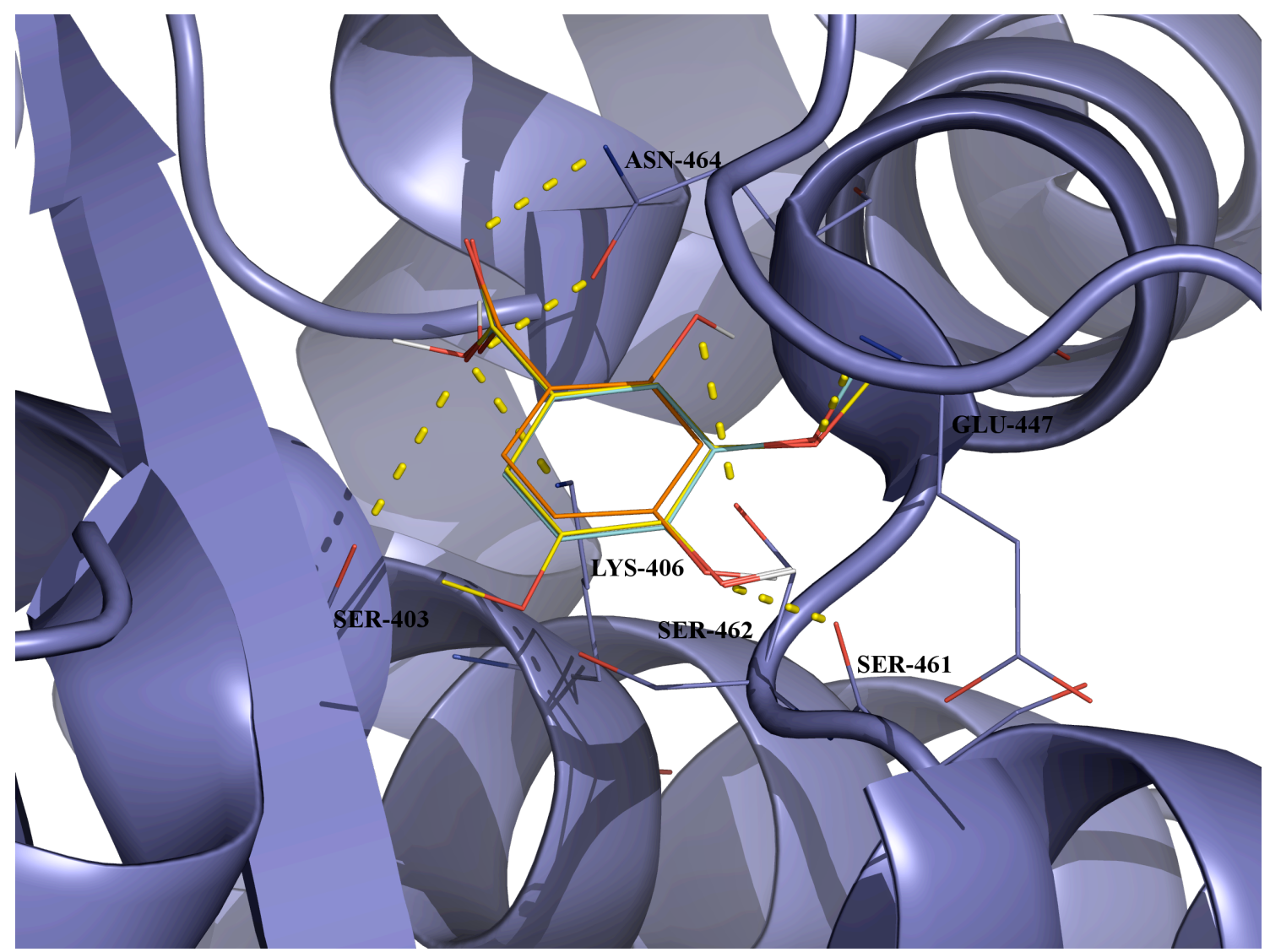

Figure 1. 2,4-Dihydroxybenzoic acid (orange), syringic acid (yelow) and vanillic acid (cyan) docking poses (lines) in PBP2a (carton blue). Hydrogen bonds are present in dash. 